\title{
Authenticity and originarity in foreign language learning in the diaspora
}

\author{
Stephan Mühr \\ Department of Modern European Languages, University of Pretoria, Pretoria, 0001, South Africa \\ E-mail: stephan.muehr@up.ac.za
}

\begin{abstract}
This paper reflects on a telecollaborative project with second-year students of German between the University of Pretoria (South Africa) and Colgate University (United States of America) in 2008. The project resulted from a critical discussion on the potential of online technology in foreign language learning (FLL). A central concern in implementing such technology should be the all-inclusive, authentic use of all language faculties, which Peeters (2008) calls "originarity". The latter overcomes structuralist or poststructuralist reductions of language as a medium of communication. Thus, the essence of FLL can be redefined, not as the acquisition of mimicry of specific codes, but as intercultural dialogue.
\end{abstract}

Keywords: originarity, authenticity, foreign language learning, video conferencing

\section{Introduction}

This paper discusses a telecollaborative (TCL) project with second-year students of German. The project, run in 2008, involved collaboration between the University of Pretoria in South Africa and Colgate University in the United States of America (USA). This project resulted, (i) from several discussions on the diaspora situation of German in both South Africa and upstate New York, (ii) from a critical debate on how computer-assisted language learning (CALL) and online communication could ideally be used for the purposes of foreign language learning (FLL), and (iii) as a response to various arguments against communicative approaches to FLL.

In the second section of this paper, I summarize these three areas of concern. I provide a rough sketch of the teaching of German at South African universities from a diaspora perspective (section 2.1). Next, I review some research on teaching German as a foreign language (FL) with online media, in order to demonstrate potential shortcomings of this method (section 2.2). In section 2.3, I introduce the rationale of originarity, the latter entailing a blurring of the difference between a "learning" situation and actual, "true" language use. It will be argued that this is the only way in which students can gain a sense of true interaction in which all language faculties are used. Section 3 demonstrates how this rationale was put into practice in the TCL project mentioned above, whereas section 4 reflects on the experience of the project and outlines potential applications of this approach to FLL. 


\section{Rationale for the telecollaboration project}

\subsection{The diaspora situation: Teaching and learning German as a foreign language in South Africa}

Although South Africa has a considerable population of German mother tongue speakers, in the past 20 years the number of students from this group registering for German at South African universities decreased dramatically (Annas 2002/2003). Instead, enrolments of students with little or no previous knowledge of German increased. These two trends compensate for each other with regards to actual enrolment figures, but qualitatively they lead to the transformation of philologically oriented German departments into mere sections of modern FLL departments. ${ }^{1}$ These students have almost no contact with mother tongue speakers of German; the FL courses offer few opportunities for immersion and contact time is usually severely limited (four to five hours per week). Moreover, these FLL students do not study German as their major or as the focus of a possible career, but consider knowledge of German to be merely an additional soft skill that increases their marketability when combined with other qualifications. Because they see the ability to speak German as only a nice-to-have, they readily discontinue German when their workload requires them to prioritize their majors. ${ }^{2}$ Consequently, throughput rates in German FLL beginners' classes are relatively low at universities. Given their reasons for taking German, students are largely extrinsically motivated. Knowing German is seen as a key to German-orientated career opportunities in business, industry or tourism; basic German skills will allow limited communication in these domains, and that is generally viewed as being sufficient. Language use itself, its functions and potential in a post-modern, global society, are not questioned or even reflected upon at all. Such an understanding of FLL is based on very crude structuralist concepts of a communicative or pragmalinguistic, functionalist utility. Consequently, FL teaching is placed under pressure to fulfil these expectations by offering language skills as a side qualification that serves market needs.

Common solutions and teaching methodologies to achieve such functionalist "outputs" are based on intensive communicative practice of the target language, but such intensive training is undermined by time constraints. Enhancement of FLL is often sought in CALL, which can offer pseudo-authentic language chunks and organized pattern drill exercises without overburdening teachers with continuous assessments. The missing link to truly authentic, interactive German speech and culture might be overcome by student exchange programmes with German universities, but for South African students this is often not possible due to the cost of participating in such programmes. Of interest to note is that the situation of German departments at South African universities is fairly similar to that of German departments at universities in the USA. ${ }^{3}$

\subsection{Language as a tool: Literature review}

CALL has become a broad field of research and discussion since the 1980s, but surprisingly little has been published on the functionality of the second generation of CALL - which not only uses information technology (IT) as a tool to convey information, but also to shape the communication situation - particularly in terms of research on teaching German as a FL. According to Warschauer and Kern (2000:1), one of the most important features of the second generation of CALL is that the learner does not communicate with the computer, but via the 
computer with humans - the term "telecollaboration" (TCL) as used by Schneider and Von der Emde (2006) is a suitable one for this approach.

Carol Twigg (2003) provides an overview of the main modes in which online technology is used in various teaching settings, summarizing the results of a multimillion dollar project of course redesign by technology in approximately 30 programmes of higher education institutions in the USA, aimed at quality enhancement and cost saving - both factors that would be directly relevant to the South African FLL context. The teaching of Introductory Spanish at three US institutions is based on a "model, in which some classes are replaced with online activities and the remaining classes are changed" (Twigg 2003:5). Instead of explaining and practising grammar rules in class, this aspect of the course is left to interactive online quizzes which students can do anywhere at any time, and the programmes make it possible for lecturers to focus on oral communication only during the face-to-face time they have with their students. As a result, "universities have been able to increase the number of students who can be served with the same personnel resources" (Twigg 2003:5). It is noticeable that Twigg's (2003) summary focuses on economic issues, rather than on academic or methodological issues. However, she fails to show the exact cost of developing online exercises and testing, merely indicating that the grant was $\$ 200000$ per institution (Twigg 2003:2).

In his dissertation, Michael Kötter (2002) reports on a tandem learning project between students in North America and Germany in a synchronous online environment named MOOssiggang. This is a derivative from an online facility named MOO, which stands for a "Multiple-user domain, Object-Oriented" (Von der Emde and Schneider 2003:122). In the introduction to his dissertation, Kötter (2002:13) argues that online written synchronicity allows "people to exchange information almost as quickly as in spoken conversation. Indeed, research ... has demonstrated that online interactions can be just as captivating as face-to-face discourse even if the partners do not see or hear each other." Kötter's (2002) comments reveal that the fascination with synchronous online communication is based on an "exchange of information" and not on the conversation as such. What exactly makes a face-to-face conversation "captivating" is not discussed by Kötter, and I would argue that it, in fact, cannot be expressed in structuralist or communicative terms.

Kötter (2002) then analyses a TCL project between Vassar College (USA) German students and English students from the Universität Münster. Using mainly discourse analysis and close observation, Kötter (2002:82-83) shows how learners adjust to the online, virtual situation and what skills and strategies they employ to manage their conversations. His conclusion indicates an interesting ambiguity: His research has shown that students successfully learned various strategies, such as the use of emoticons or highlight strategies, to compensate for the limitations of online written discourse. So, because the online written situation prevented them from using language to its full capacity and they had "to work harder to convey paralinguistic information" (Kötter 2002:236), they "increased their metalinguistic awareness" (Kötter 2002:237). Considering the terms "paralinguistic" and "metalinguistic", however, this finding shows what precisely Kötter considers to be genuine linguistic interaction: an exchange of information and nothing else. I would argue that, because the online facility reduces language use to a game of information ping-pong, students naturally had to develop strategies for compensating for this limitation of the medium through which they were interacting. In fact, most of Kötter's findings relate to precisely these compensation strategies 
- for example, the "repair work" students had to perform in online situations. Ambiguity lies in the evaluation of "success" in such "metalinguistic" conversations: We increasingly "communicate" through the use of media such as e-mail, SMS (or texting) or similar that, to a certain extent, restrict language use to exactly these strategies; studies such as that of Kötter thus investigate the success (measured in the use of compensation strategies) of communicating by means of media which necessitate (and even cause) a need for the use of such compensation strategies. Only in such a context can an outcome such as "successfully learned to develop alternative, compensating strategies" have didactic relevance: Students learn to succeed (or survive) in a brave new techno-world by developing strategies to virtualize humanity in alienating codifications. Instead of experiencing laughter in class, they "lol". The CALL approach to FLL affirms such reduced language practices.

Silke von der Emde and Jeffrey Schneider are experienced researchers and practitioners in adopting and adapting online media for German FLL programmes in the USA. Their articles since the late 1990s reflect an interesting shift from CALL to TCL. The review given below of two of their articles (2003 and 2006) may represent this shift in the discourse on FLL.

In the title of Von der Emde and Schneider's 2003 article, Experiential learning and collaborative reading: Literacy in the space of virtual encounters, the tendency towards an authentic learning situation is already preformulated in terms such as "experiential" and "encounters", but the dominant discourse remains the online technology. With regard to the adaptation and development of MOOs as a mainly written, interactive, online tool, Von der Emde and Schneider (2003) stress the role of higher-domain literacy in FLL and its connections with critical thinking, based on the (then) latest findings on general FLL practices. Texts and text analysis (even beyond MOOs, I would argue) serve as an ideal tool to achieve the aim of "transform[ing] the lower-intermediate language class into a cultural studies seminar" (Von der Emde and Schneider 2003:5). The main argument for using this tool rather than face-to-face communication is that technology-enhanced communication shapes the form of communication itself, making students aware of the very mediality and its function in communication. This, therefore, becomes a direct outcome in itself, serving linguistic awareness. At this stage, the issue of linguistic awareness (as a higher domain of critical thinking) is still a supplementary outcome of the online activity, rather than the primary didactic outcome of the FLL syllabus. This finding reveals the distorting character of online language practice which Kötter's (2002) findings also implied.

The case study that Von der Emde and Schneider (2003) present is based on reading texts from the beginning of the 20th century with the overarching topic "Space and identity", which is an important dimension of that period, its literature and prevailing culture. This activity focused on collaborative reading (Von der Emde and Schneider 2003:7) as intensive studentcentred online group-work. They cite synchronous logs of the MOO activities, which functioned similar to chats, but additional "background texts" were available to the students. Citing Roche and Webber (1995), Von der Emde and Schneider (2003:9) argue that it is important that "instruction must give students the possibility to work on complex topics even with their limited means of linguistic expression". In this regard, the cited log shows that the students engaged in a fairly complex interpretive discussion about what the text means.

MOOs were also used in "experiential reading" (Von der Emde and Schneider 2003:127) in alternation with creative writing assignments. The creative outputs, they argue, function only 
if they are also valued by a follow-up, shared, interpretive exercise. The assignment was to describe a virtual residence room, and the follow-up exercise of validation asked the students to choose a house-warming gift for the owner of the room and write a letter explaining it. The choices unlocked many interesting personal and cultural issues. The class discussions following the exercises also demonstrated the level to which students developed critical thinking. Von der Emde and Schneider (2003:132) interpret this as one of the advantages of MOOs or the Internet: "As Sherry Turkle suggests, the MOO - like the Internet more generally - 'has become a significant social laboratory for experimenting with the constructions and reconstructions of self that characterizes postmodern life'."

In their concluding remarks, Von der Emde and Schneider comment on a specific exercise of reflection, during which they gave students the same literature on FLL theory which they were drawing from themselves. This allowed students to reflect on their own learning strategies and "involve[d] them as collaborators with us" (Von der Emde and Schneider 2003:139). Teacher and learners experimented and discussed what they were doing together. The experience of restricted language use in an online environment triggered the discussion about the broader functions of language and was made an explicit topic by this reflection. In addition, making students collaborators and aware of a learning strategy not only fosters intrinsic motivation in such students, but also increases authenticity - at least at this level of reflection, students and teachers can truly engage in a dialogue in the fullest sense of language use.

A more recent article by Schneider and Von der Emde (2006), Conflicts in cyberspace: From communication breakdown to intercultural dialogue in online collaborations, marks a further shift from communicative models towards a new validation of online FLL, as revealed in the opening remark on a search for "the real thing" - "and that is authentic communication" (Schneider and Von der Emde 2006:179). Whereas previous models preferred the term "communication", this term is now viewed as being inflationary and is thus disregarded. Instead, "dialogue" could embrace the authentic use of language much better. Particularly in intercultural situations, dialogue involves curiosity and openness and a "broader set of skills to obtain knowledge from the other culture as well as the necessity to make own values explicit" (Schneider and Von der Emde 2006:181-182). European theory on intercultural dialogue, however, seems to exclude the term "conflict", even suggesting its avoidance. ${ }^{4}$ However, referring to Mikhail Bakhtin, Schneider and Von der Emde (2006:182) argue that language is always a result and a site of struggle or conflict. It always involves interpretation and the exertion of accomplishing own concepts. We talk in order to make our voices heard. As a site of struggle, ${ }^{5}$ language not only influences both interlocutors, but also shapes the very form of their dialogue. Such changes, if they are reflected upon as a meta-topic of FLL, indeed allow a discussion of "the real thing".

Schneider and Von der Emde (2006) report on a practice-based TCL between Vassar College and Münster University students in 2003. Student interactions were again facilitated by MOOssiggang, as well as web activities based on the relevant Blackboard sites. For the following argument, I focus on some aspects that I regard as particularly relevant to demonstrate the shift towards authenticity and the full use of language capacity:

(i) The notion of 'additional outcomes': The purpose of the TCL not only referred to language learning outcomes (this would automatically lead to inauthentic 
communication), but rather to critical cross-field outcomes: a critical understanding of technology in FL teaching for the students from Münster and of media studies for those from Vassar (Schneider and Von der Emde 2006:184). In addition, intercultural learning was an explicit outcome, and students had to reflect on the development of their intercultural competences gained through the TCL experience.

(ii) The notion of 'additional topics': Following the above principle, the topic which students were telecollaborating on was the intercultural analysis of the school shootings in the USA in 1999 and in Germany in 2002, and how the public and the media responded to them. By discussing issues of language use and of (cultural) identity and stereotypes surrounding such a topic, students authentically wanted to take a stance on it. In fact, the discussions were so productive that "they also became springboards for continuing the dialogue" (Schneider and Von der Emde 2006:193).

(iii) The emphasis on reflection and meta-reflection: To make such intercultural dialogue about authentic experiences explicit to the students, they need space to "step back". By means of summarizing and in-group discussion and the use of secondary texts (in their mother tongue) on issues of intercultural dialogue as well as on cultural stereotypes and language learning, the critical cross-field outcomes became explicit learning content. Students learned that a FLL class offers more than simply mimicking a native speaker (Schneider and Von der Emde 2006:197).

In their conclusion, Schneider and Von der Emde (2006:198) admit that a "true" authentic dialogue entails a lot of risks for the FLL setup: Students might feel embarrassed because they are confronted with real opinions that might differ from their own world views; teachers might lose control for the same reason. However, the experience they encounter is authentic and these students did learn something about the actual functioning (Wirkung) of language and culture by using it authentically (Schneider and Von der Emde 2006:200). Schneider and Von der Emde (2006:200) acknowledge that the online situation lacks "paralinguistic meaning signals" and entails "constraints and affordances for intercultural learning". However, such risks are imperative after 9/11. They conclude that "FL programs need to offer more than language instruction for communicative purposes" (Schneider and Von der Emde 2006:200).

A comparison of the reviewed articles demonstrates a shift away from the term "communication" towards broader terms of language use, and subsequently a growing ability to see the limitations of online technology for FLL. The IT-affirmative argument that online communication leads to critical awareness had almost disappeared by 2006 . Instead, a way to use the internet for higher-level, authentic FLL encounters was found. The use of online discussions as described by Schneider and Von der Emde (2006) opens up the traditional reading of a "book" (text analysis) to a new possible means of discussion or dialogue with a "living book". Using online tools in such a manner creates completely new opportunities, provided that the defined outcomes of such courses in FLL are also revised.

That said, for the planning of FLL, the use of online media must be a subordinate question. The first question should remain the use of language in an authentic manner conducive to real interaction in and with the FL. Only after that issue has been resolved can one investigate the potential of online media to that end. ${ }^{6}$ In this regard, the comparison of the two articles by Schneider and Von der Emde demonstrates the cardinal shift in the use of IT. If language is regarded as an abstraction (langage) of encoding and decoding processes (parôle), IT 
applications to FLL would be seen as a variety of channels or meta-codes (such as emoticons) that students have to learn to use effectively. Successful management of this skill could then be termed "critical online media awareness". "Conflict" would be understood as coding error and "authenticity" would equal successful decoding of information. On such a view, language is understood to refer only to an information ping-pong, which can also occur between automated systems. However, if language is regarded as a living, procedural means of being human and maintaining humanity, existing IT media can both help and hinder users, as Schneider and Von der Emde (2006:200) acknowledge. Authenticity could then be regarded as the acceptance of the mutual Wirkung of the dialogue on the ontological self-awareness of the interlocutors as well as the acceptance of the dialogue as a concrete experience of being in the world.

The implementation of meta-outcomes over and above mere language proficiency skills means far more than simply following the cultural turn. In fact, it reintroduces such domains of hermeneutical learning as "cultural" or "intercultural competences" that were dismissed from FLL during the structuralist period.

\subsection{Beyond authenticity: The concept of 'originarity'}

The above discussion of some recent literature shows that there are common misunderstandings regarding the status and function of authenticity in FLL. Even at a very pragmatic level, the famous role-plays in FLL practice are all counterfeit. Some examples of seemingly authentic (but in fact inauthentic) tasks include assignments such as "Write an email to a student, inviting him/her to a party. Be creative (marks are awarded for originality)." or a web search assignment such as "Find and compare the prices of three given household items on the websites of the German dealers Media Markt and Saturn".

Considering the ontological status of language, every exercise restricted to language use only is by nature inauthentic. For that reason, Schneider and Von der Emde introduced additional outcomes to the FLL syllabus. The review in section 2.2 also demonstrated that communicative models are not suitable to describe this authentic language use and its peculiarities. In response to these problems, Leopold Peeters (2008) has developed a new term, "originariteit" (an Afrikaans term which I translate as "originarity"), ${ }^{7}$ which, as this paper attempts to show, can be applied to FLL situations.

Peeters excavates and reanimates insights into the role of language that were buried in the structuralist movements of the 20th century. With the term "originarity", he emphasizes the essence by which something comes into existence. It explains the emergent potentials of language and its ontological human status. With this term, Peeters points to language being (i) a phenomenon - Peeters (2008:30-33) uses the Afrikaans term "taalgebeure" [= 'language events'] - and (ii) part of our human potential or ability - Peeters (2008:37-39; title) terms it "taalvermoë" [='language ability']. Comparing the abstract term "language" to the concrete term "speech", he concludes that when one looks at language as speech and its meaning as "originarity", speech is clearly a phenomenon by which at least two people meet and experience themselves in an interpersonal, dialogical togetherness. To cross-check this argument, he analyses the famous Cogito ergo sum of Descartes, demonstrating that even in monological, written speech, an interpersonal relation must at least be hypothesized in order to make sense, because language is inter-subjective (Peeters 2008:32). 
Peeters draws on the work of many language philosophers, ranging from Wilhelm von Humboldt's description of language as a power of the soul that comes into existence in a dialogue (Peeters 2008: 36) ${ }^{8}$ to Hölderlin's view of language as a combination of the expression of ideas (ergon) as well as their potential creation (energeia) (Peeters 2008:36-37), and goes back via Wilhelm von Ockham to the concept of the zoon logon echon postulated by Aristotle: The term echein includes the reverberating of speech, as well as bearing speech in a physical sense. To have a language is much more than being able to manage a set of codes; it is "'n wesentlike kwaliteit of manier om te wees of om dit wat is op te neem, te dra, in werking te stel" [= 'an essential quality or manner to be or to assimilate, carry and put into practice that which is'] (Peeters 2008:43). Humans have to externalize their existence by means of language; we have to speak in order to be able to experience ourselves as being(s) in the world. Peeters (2008:51) summarises it as follows:

Van die mens as synde beteken dit dat die mens 'n mimeties spelende en van binne uit herskeppende antwoord kan gee op die roep van die wêreld, van die natuur of van die ander waarmee hy in elk geval in sy diepste wese onafskeidelik verbind is. As sulks kan die mens sin gee aan sy bestaan. [='From the perspective of man as a being, this means that man can give a mimetic playful and from-the-inside-recreating answer to the call of the world, of nature or of the other(s) with which he in any case in his deepest being is inseparably connected. As such, man can give meaning to his existence.']

Kramsch, A'Ness and Lam (2000) argue in their paper that authenticity and authorship have given way to agency and identity in internet-mediated language use. Their interpretation of two case studies is based on a discussion centered on authenticity and authorship as "the two tenets of communicative language teaching" (Kramsch et al. 2000:78). In fact, quoting Widdowson (1992:149), they argue that the term "authenticity" never was truly acceptable in a classroom situation. Traditionally, the term referred to "the use of the spoken language in conversational interactions" (Kramsch et al. 2000:80) and by a native speaker (Kramsch et al. 2000:78). In their paper, a communicative perspective on language is maintained, although they indicate at the end of their abstract that "computer-mediated communication leads us to rethink the authentic, the authorial, and, ultimately, the communicative itself" (ibid.). Their concept of communication mainly refers to David Graddol (1994) who identifies three models of (communicative) language description. The first model, which is the structuralist model, understands meaning as referential meaning (Kramsch et al. 2000:81) that every participant agrees on. Model 2 is termed "a social model" (ibid.) in which meaning is understood as socially and historically constructed in the context of the relevant communication. This model "foregrounds authenticity ... rather than authority" (ibid.). I regard authenticity and authorship as two sides of the same coin: From a receptive perspective, authenticity refers to authentic texts or dialogue, as in model 2; from a productive perspective, authenticity refers to the concept of authorship, as in model 1. The third model, which is the "post-modern" or "media" model, is concerned with signs rather than with words, where all human practices serve communication. Referring to Bourdieu, "communication in this model is a site of struggle to be heard, noticed, understood" (Kramsch et al. 2000:82). The latter reminds clearly of Peeters, although he is coming from a different perspective, as the "struggle to be heard, noticed, understood" could be regarded as the conscience of being alive, of being. Even the argument that, in this model, "a text will take on a different life, new functions and new meanings" (ibid.) coincides with Peeters' originative, emergent function of language. But here, 
"authenticity and authorship [shift] to goal-oriented action and agency" (ibid.). Peeters' (2008:42) concept of authentic language being originative clearly matches the conclusion reached at the end of Kramsch et al.'s (2000:83) theoretical chapter: "By being 'actants' ... we find out who we are and who we are making ourselves to be."

Transferring these thoughts onto social psychology and concepts of identity, one can say that language activity in its originary sense is always a (re-)negotiation of personal selfrealisations (cf. Laing, Phillipson and Lee 1971:11-51). We speak in order to engage with others about the world we live in. Speaking keeps us in contact with the world and with our human nature. Learning a (foreign) language is thus not the acquisition of a code, but of wisdom about how to enter into relations with others around the world. A foreign language course should, therefore, endeavour to create situations in which students use language truly to engage with people in order to do something in this world. Making students aware of and inviting them to reflect on such processes is the meta-outcome of a FLL course (cf. Schneider and Von der Emde 2006), sensitizing them to the role that language plays in everyday life, as well as the value of learning a FL.

Furthermore, such linguistic processes of originarity can best be studied in text analysis, because texts document how people of different times, cultures and circumstances exist(ed) in the world. Text analysis is an indispensable skill that is relevant to almost all modern careers, no matter how economically driven they are. It is inherently a "language-reflective act", as Schneider and Von der Emde (2006) describe it. By reflecting on the role of self-realisation and interpersonal relations in authentic talk and text, students learn to create a stable identity themselves, and to consciously manage identity in an intercultural situation.

\subsection{Implications for the project}

In applying these considerations to a practical case of teaching German as a FL, I adhered to the following leading principles: ${ }^{9}$

- Student engagement has to be taken beyond the language learning outcomes. Instead, one must seek to achieve meta-outcomes (the ability to present and defend their identity in the target language) and find appropriate topics (interpersonal perception and identity, the identity of Germans living in the diaspora, the dangers and risks of language and construction of identity).

- In order to reach true, authentic communication in the sense of originarity, students should collaborate on these topics with peers.

- Due to the diaspora situation, this could be done by means of online support in a TCL with other students, or with German-speaking diaspora inhabitants of South Africa and upstate New York.

- Such a project should include reflection on these topics and on the experience of originarity in order to address and develop the critical cross-field outcomes of an intercultural competence that could be redefined as the competence of successfully practising originarity by using the German language.

\section{The project}

This report reflects on a project undertaken in the first semester of 2008 (from February to April) with second-year German FLL students at the University of Pretoria in South Africa and at Colgate University in the USA. Both classes were of a similar size (8-10 students) and 
progression status (about B2 according to the CEFRL), and in both regions a German diaspora situation as described in section 2.1 is found. Drawing conclusions from the experience of Schneider and Von der Emde as summarized above as well as Peeters' concept of originarity and its implications for FLL, the two lecturers at the respective institutions decided together on a common curriculum, consisting of three units on which I will elaborate below. They chose to use the Colgate Blackboard portal as the forum of documentation. Each unit was concluded with a one-hour video conference. Video-conferencing was regarded as a more originative medium than MOOs or chats. In applying the considerations regarding originarity and meta-outcomes, the lecturers agreed to discuss the role that language plays as a means of being (identity) and of relating to others beyond a communicative transfer of data (interpersonal relations). Each of the units of the curriculum will be discussed below.

\subsection{Unit 1. Ars Intelligendi: ${ }^{10}$ Originarity and interpersonal perception}

The first unit dealt explicitly with interpersonal perception by reading and reflecting on the first chapter of Laing, Phillipson, and Lee's book on Interpersonal Perception (Laing et al. 1971:11-42). This chapter gave students basic insight into the concepts 'ego' and 'alter', 'I' and 'Me' (cf. Mead 1934), of 'identity alteration' and 'plurality of identities' in interpersonal interaction, as well as the need for interpretation and projection during interactions. With this background, students were then tasked with introducing themselves on a Blackboard roster organised in a similar fashion to Facebook. In a second step, students analysed the introduction of a student from the partner university and presented their findings to the (local) in-group. From this, they formulated a "profile of expectations" about this person. During the video conference, students took turns to present their expectation profiles without identifying the student. Then, with muted microphones, each group discussed who was described and how the expectations came about. In a final round, both groups shared their findings. A debriefing exercise was used as a reflection: "Reflect on what was described correctly and what was wrong. Reflect how these expectations came about."

In order to demonstrate the originarity that was unlocked by this exercise, I quote one example. The introduction given by one Colgate student reads as follows (cited verbatim, but ignoring grammatical errors):

Ich heisse Bill Watson. ${ }^{11}$ Ich bin achtzehn Jahre alt und komme aus Boston, Massachusetts. Ich gehe jetzt auf die Colgate Universität und bin in meinem zweiten Semester. Ich werde Mathematik studieren und Deutsch lernen an die Universität.

Personal Information

Ich habe eine Schwester und einen Bruder. Ich spiele gerne Basketball und ich laufe für die Leichtathletikmannschaft von Colgate. Ich finde alle Musik gut, aber ich habe Rap und Techno am liebsten.

Favorite Links

ESPN.com: Ich liebe Sport und ESPN gibt die beste Information. http://facebook.com/Facebook: Ich habe viele Freunden, mit denen ich sprechen möchte, aber ich habe nicht genug Zeit. Facebook ist ganz gut, um schnell mit anderen Leuten zu sprechen. ${ }^{12}$

The expectation profile that Pretoria students developed from this information was as follows: 
Es ist schwierig um ihn lern zu kennen, weil er nichts Genaues über sich selbst, und was ihm gefällt ihn sagt, aber er muss freundlich sein, weil er sich mit seinem Rufname vorstellt.

Er scheint Sport zu genießen, und das reflektiert sich auf seinem Photo. Er sagt nicht viel über sich selbst: er muss ein bisschen schüchtern sein. Reflektiert sein Liebe für einen Einzelnsport, irgendwas über seiner Persönlichkeit?

Zum Abschluss: ist da eine Beziehung zwischen Mathematik und Deutsch? Seine Liebe für Sport ist vielleicht ein Zeichnen, dass er einer Einzelgänger ist. ${ }^{13}$

This profile demonstrates how the students got involved in getting to know each other. Issues such as Freundlichkeit [='friendliness'] versus writing a polite expectation profile, or the relation between "Einzelsport" [='individual sport'] and personality or even the stereotypical relation between mathematics and language skills came to the fore. The creator of the expectation profile was very careful not to jump to conclusions - but since the task was to come up with expectations that should be "tested" in reality, these expectations served as manifestations of processes that indeed happen in interpersonal perceptions. This is exactly what makes originary language use risky (cf. Schneider and Von der Emde 2006:198; Peeters 2008:29).

This was even more obvious in the final task which required students to reflect on the experience. Students presented to the in-group a brief oral reflection on what was described correctly and what incorrectly and why they guessed the expectations had come about. Almost all the expectation profiles were approved by those they described. Where descriptions were not fully accurate, this was due to slight misconceptions that indicated the deep interpersonal involvement and personal experience of originarity. The following sentences are excerpts from the class discussion:

Peter (who thought he was described much too positively): "Ich bin zu introvertiert und faul, um hilfsbereit zu sein." [='I am too introverted and lazy to be helpful.']

Jan (who thought he was described accurately): "How could they know, I am schüchtern [='shy'] and how my room looks like? I even have two sci-fi posters on the wall!"

\subsection{Unit 2: Ars Explicandi: Germans in the diaspora}

The second unit was aimed at a project derived from the diaspora situation. Having experienced the construction of identities by speaking German to strangers from across the Atlantic, the ever-prevalent question for German FL students is: "Why do I study this language and why is it taught in this remote place?" Students investigated how German mother tongue speakers in their immediate vicinity were maintaining their identities in the diaspora. They were tasked with interviewing German mother tongue speakers on their identity as being "German" in upstate New York and in South Africa, and on the role their mother tongue plays in their lives. The results, focusing on identity and the questions about what makes somebody "a German", were presented during the second video conference in a proper conference mode. Table 1 provides an overview on the research projects of the students. 
Table 1. Student research projects

\begin{tabular}{|c|c|c|}
\hline & \begin{tabular}{|l} 
Deutsche in upstate New York \\
{$[=$ 'Germans in upstate New York'] }
\end{tabular} & $\begin{array}{l}\text { Deutsche in Südafrika } \\
{[=' G e r m a n s \text { in South Africa'] }}\end{array}$ \\
\hline 1 & $\begin{array}{l}\text { Deutsch-Fähigkeiten und Deutsch-Interessen } \\
\text { auf dem Colgate Campus. Wer? Warum? } \\
\text { Wichtig für Position? [='German proficiency } \\
\text { and German interests on Colgate campus. } \\
\text { Who? Why? Important for position?'] }\end{array}$ & $\begin{array}{l}\text { Deutsch-Fähigkeiten und Deutsch- } \\
\text { Interessen auf dem Campus der } \\
\text { Universität Pretoria (UP). [='German } \\
\text { proficiency and German interests on the } \\
\text { campus of the University of Pretoria } \\
\text { (UP).'] }\end{array}$ \\
\hline 2 & $\begin{array}{l}\text { Geschichte des Deutschen / der } \\
\text { Deutschabteilung an der Colgate University. } \\
\text { Wann begonnen? Welche Kurse? Welche } \\
\text { pädagogischen Ziele? Welche Programme? } \\
\text { [='History of Germans / the German Division } \\
\text { at Colgate University. When started? Which } \\
\text { courses? Which pedagogical aims? Which } \\
\text { programs?'] }\end{array}$ & $\begin{array}{l}\text { Geschichte der deutschen Mission in } \\
\text { Südafrika. [='History of the German } \\
\text { mission in South Africa.'] }\end{array}$ \\
\hline 3 & $\begin{array}{l}\text { Deutsch an Schulen und Universitäten in } \\
\text { upstate New York. Umkreis etwa } 60 \text { Meilen. } \\
\text { [='German in schools and at universities in } \\
\text { upstate New York. Radius of about } 60 \\
\text { miles.'] }\end{array}$ & $\begin{array}{l}\text { Deutsche Schulen in Pretoria / Südafrika. } \\
\text { [='German schools in Pretoria / South } \\
\text { Africa.'] }\end{array}$ \\
\hline 4 & $\begin{array}{l}\text { Deutsche Firmen und Geschäfte im Umkreis } \\
\text { von etwa } 60 \text { Meilen. [='German businesses } \\
\text { and shops in a radius of about } 60 \text { miles.'] }\end{array}$ & $\begin{array}{l}\text { Deutsche Firmen und Geschäfte in } \\
\text { Gauteng. [='German businesses and shops } \\
\text { in Gauteng.'] }\end{array}$ \\
\hline 5 & $\begin{array}{l}\text { Deutschsprachige Einwanderer in upstate } \\
\text { New York: Gründe für das Verlassen des } \\
\text { Heimatlandes. Gründe für deutsche } \\
\text { Siedlungen in upstate New York. [='German- } \\
\text { speaking immigrants in upstate New York: } \\
\text { Reasons for leaving their home country. } \\
\text { Reasons for German settlements in upstate } \\
\text { New York.'] }\end{array}$ & $\begin{array}{l}\text { Deutschsprachige Einwanderer in } \\
\text { Pretoria. [='German-speaking immigrants } \\
\text { in Pretoria.'] }\end{array}$ \\
\hline
\end{tabular}

\subsection{Unit 3: Ars Applicandi: Literary analysis of Bernhard Schlink's Der Vorleser}

The final unit was an application of the overarching topic of "identity in the making by language use" by doing a literary analysis of Bernhard Schlink's Der Vorleser (1995). This novel demonstrates an extreme case of how the use and the avoidance of (written) language construct "world" and "identity". The closing video conference was organized in the form of a prepared panel discussion.

The rationale for using a literary text analysis was discussed in the review of Von der Emde and Schneider's (2003) article: Meaning is created by the author, the text and the reader. It is actually of particular interest to see how "foreign" readers construct meaning from texts. Referring to Kramsch (1997), Von der Emde and Schneider (2003:4) explain that "notions of pleasure and self-actualization may be more important objectives for foreign language reading" than conventional reading comprehension, which goes hand in hand with an originary understanding of language use. It was concluded that it would be even more 
interesting and originary to have non-native speakers from different cultural backgrounds discuss and reassess their self-actualizations in relation to a literary text. Accordingly, the outcomes envisaged in the cross-Atlantic reading of Der Vorleser focused less on comprehension than on the following leading questions for the video conference:

(i) Ist Der Vorleser relevant (a) für Amerikaner/Südafrikaner, (b) für die Generation, die jetzt studiert (nach 1980 geboren)? [='Is Der Vorleser relevant (a) for Americans/South Africans, (b) for the generation that is currently studying (born post1980)?']

(ii) $\mathrm{Zu}$ welchem Genre gehört die Erzählung? Unterhaltungsliteratur? [='To which genre does the story belong? Light reading?']

(iii) Gelingt Schlink mit seinem Buch eine echte Auseinandersetzung mit dem Holocaust, oder wird das Thema trivialisiert? [='Does Schlink succeed to give a true exposition in this book of the holocaust, or is the topic trivialized?']

(iv) Warum wurde es so ein Erfolg? [='Why did it become such a success?']

(v) Was erwarten Sie von dem Film, der gerade gedreht wird? [='What do you expect from the movie, which is currently being produced?']

For the Pretoria students, this panel discussion also served as an oral examination. However, many of the students said afterwards that the examination was not in the foreground of their minds at all. The discussion was well-centred around the topics, and students participated actively and wanted to have their say. All of this occurred in German, but the focus of the discussion was on the overarching topic.

\section{Conclusion and vision for the future}

Student evaluations of the project did not necessarily reflect high levels of enjoyment, but that was not the aim of the project. As Schneider and Von der Emde (2006) pointed out in their concluding remarks, true dialogue and conflict pose risks and may create embarrassment, because experiencing life by means of language includes conflict and embarrassment. ${ }^{14}$ The aim of the project was originarity. So, students experienced themselves and others and their existence by means of foreign language use. Such experiences are not all necessarily enjoyable, but are linked to learning. What is of interest here is that students continued to discuss Schlink's novel even after the conference was completed.

Students need to become familiar with the internet facilities, including the video-conferencing facility. As the literature review shows, this cannot be the main outcome of FLL, but it is a necessary goal in order to effectively use electronic media. If achieved, however, TCL indeed offers potential beyond conventional methodologies, in particular to departments with low student enrolments: "For departments struggling with enrolments, as many German Studies departments are, it is important that students find the rewards of learning a FL enough of a motivation to enrol in more advanced courses" (Schneider and Von der Emde 2006:199).

Internet speed in South Africa is acceptable. The recent commissioning of a new undersea cable has enabled a doubling of the international bandwidth at the same cost. This makes the use of TCL by South African academic departments increasingly feasible. 
The TCL of German FLL students in highly comparable situations (in South Africa and in the USA) proved to be very successful and interesting. One might argue that collaboration with native speakers in a tandem situation such as in the case of Münster and Vassar might be even better. The advantages of a third-party collaboration include a more heterogeneous, plural approach towards "German" and a triangulation of own identities towards learning German. The advantage of using German mother tongue speakers as partners would be a higher personal stake, but it may reduce the situation to a bipolar structure. Similar collaborations, for example with other African students learning German, might lead to interesting discoveries about facets of African identity, African-European relations and different motivations of African students for learning German. Finally, TCL even between the German students of two South African universities would certainly create originary dialogue and learning experiences.

\section{Notes}

1. The Universities of Cape Town and South Africa, for example, will close their German postgraduate programs at the end of 2009.

2. A survey conducted at the University of Pretoria in 2009 among first-year German students revealed that only $25 \%$ are registered in language-related degrees. The expectation that most students $(60.4 \%)$ have of the course is to gain basic communicative skills in German.

3. This judgement is based on a one-year experience of the author in the German section at Colgate University in 1995 and ongoing discussions with American colleagues (cf. note 9).

4. Schneider and Von der Emde (2006:182) refer to Byram, Gribkova and Starkey 2002 and Byram, Nichols and Stevens 2001 in this regard.

5. Peeters (2008:29) also stresses the potential danger or risk that goes hand in hand with using language to its full capacity, because speaking - in his understanding of originarity (to which we return in section 2.3) - means that "die wordende mens uit daardie beproewing verswak of versterk te voorskyn kan tree. ... Ervaring opdoen is ' $n$ persoonlike uitdaging wat nie sonder gevaar is nie, mits dit hier gaan om die sin van my eie bestaan." [='the emerging person can exit from that trial weakened or strengthened. ... Gaining experience is a personal challenge which is not without its dangers, because the sense of my own existence is at issue']. This correlates well with interactionist theory, for example with Ervin Goffman's (1969) explanations on the interactionist construction of identity or Laing, Phillipson and Lee's (1971) 'interpersonal perception'.

6. I would like to give credit for this very fundamental principle to Vasilis Koulopoulos, Educational Technologist at Columbia University.

7. I translated Peeters' Afrikaans term "originariteit" into English: "[Ek het] die term 'originariteit' gevorm ... op die byvoeglike naamwoord 'originêr' wat in die Afrikaanse verklarende woordeboek van Kritzinger et al. (1965:591) voorkom met die betekenis van 'wesentlik-oorspronklik, soos dit in die oervorm is, nie afgelei nie'. ... Originariteit dui dus op die aard van 'n daadwerklike proses in die sin dat dit 'n uitwerking of gevolg kan hê en dus iets nuuts in die wêreld laat ontstaan." [='I coined the term "originariteit" from the adjective "originêr" which occurs in the Afrikaans dictionary of Kritzinger et al. (1965:591) with the meaning "essential-original, as in its original form, underived." Originarity thus indicates the nature of a real process in the sense that it can have an effect or consequence and can thus bring something new into 
existence in the world.'] (Peeters 2008:29). The Oxford Encyclopedic English Dictionary (Hawkins and Allen 1991) only refers to the term "originate" and not to "originarity". The New Shorter Oxford English Dictionary on Historical Principles (Brown 1993(II):2022) lists three rare meanings for "originary": "†1 Native to or of a given place. 2 That is the origin or source of a person or thing. $\dagger 3$ Arising directly; primary; underived." It also lists the adjective "originative", being probably closest to Peeters' use, as "having the quality or power of originating; creative" (ibid.).

8. Peeters (2008:36) refers to Humboldt's Introduction to the Kawi Grammar. There, Humboldt (1836:xxiv) uses the term "menschliche Geisteskraft" [='human mental ability'] and explains: "Die Hervorbringung der Sprache ist ein inneres Bedürfniß der Menschheit, nicht bloß ein äußerliches zur Unterhaltung gemeinschaftlichen Verkehrs, sondern ein in ihrer Natur selbst liegendes, zur Entwicklung ihrer geistigen Kräfte" [='The emergence of language is an internal need of human beings, not merely something external for the maintenance of collective social interaction, but something which lies in human nature itself, for the development of man's mental capacities'] (Humboldt 1836:xxv). This quotation already indicates an anti-communicative approach by Humboldt, and also gives an explanation to Peeters' development of the term "originarity" from "Hervorbringung" [='emergence'].

9. I thank Dierk Hoffmann from Colgate University with whom I worked out these principles and developed and conducted the TCL project in 2008. His didactical and technical support was indispensable.

10. The course outline strictly follows a hermeneutic structure of coming to understanding, starting with ars intelligendi, practising by ars explicandi and appropriating it by ars applicandi (cf. Gadamer 1972:312).

11. Original names and identifying data of students have been changed throughout this article.

12. Loose English translation: "My name is Bill Watson. I am 18 years old and come from Boston, Massachusetts. I am currently attending Colgate University and am in my second semester. I will study Mathematics and learn German at university

Personal Information

I have a sister and a brother. I like to play basket-ball and I run for the athletics team of Colgate University. I find all music good, but I like rap and techno best.

Favorite Links

ESPN.com: I love sport and ESPN gives the best information.

http://facebook.com/Facebook: I have many friends to whom I would like to speak, but I don't have enough time. Facebook is very good for quickly talking to other people.

13. Loose English translation: "It is difficult to get to know him, because he doesn't say anything specific about himself or about what he likes, but he must be friendly, because he introduces himself using the name by which he is known.

He seems to enjoy sport, and that one can see from his photo. He doesn't say much about himself: He is probably a little shy. Does his love for individual sports reflect something about his personality?

In conclusion: Is there a relationship between Mathematics and German? His love for sport is perhaps a sign that he is a loner."

14. Cf. note 5 . 


\section{References}

Annas, R. 2002/2003. Zur Situation des Faches Deutsch an südafrikanischen Universitäten. Acta Germanica 30/31: 181-191.

Brown, L. (eds). 1993. The new shorter Oxford English dictionary on historical principles. Oxford: Oxford University Press.

Byram, M., B. Gribkova and H. Starkey. 2002. Developing the intercultural dimension in language teaching. Strasbourg: Council of Europe.

Byram, M., A. Nichols and D. Stevens. 2001. Introduction. In M. Byram, A. Nichols and D. Stevens (eds). Developing intercultural competence in practice. Clevedon: Multilingual Matters. pp. 1-8.

Gadamer, H.-G. 1972. Wahrheit und Methode. Tübingen: J.C.B. Mohr.

Goffman, E. 1969. The presentation of self in everyday-life. London: Allen Lane.

Graddol, D. 1994. Three models of language description. In D. Graddol and O.Boyd-Barrett (eds). Media texts: Authors and readers. Clevedon, UK: Multilingual Matters. pp. 121.

Hawkins, J.M. and R. Allen (eds). 1991. The Oxford encyclopedic English dictionary. Oxford: Oxford University Press.

Humboldt W.v. 1836. Über die Kawi-Sprache der Insel Java, nebst einer Einleitung über die Verschiedenheit des menschlichen Sprachbaues und ihren Einflu $\beta$ auf die geistige Entwicklung des Menschengeschlechts. Berlin: Königliche Akademie der Wissenschaften.

Kötter, M. 2002. Tandem learning on the Internet: Learner interactions in virtual online environments (MOOs). Frankfurt/Main: Peter Lang.

Kramsch, C. 1997. The privilege of the nonnative speaker. PMLA 112: 359-369.

Kramsch, C., F. A'Ness and W.S.E. Lam. 2000. Authenticity and authorship in the computermediated acquisition of L2 literacy. Language Learning \& Technology 4(2): 78-104.

Laing, R.D., H. Phillipson and A.R. Lee. 1971. Interpersonelle Wahrnehmung. Frankfurt / Main: Suhrkamp.

Mead, G.H. 1934. Mind, self and society. Chicago: University of Chicago Press.

Peeters, L. 2008. Taalvermoë en originariteit. Acta Academica 40(2): 28-52.

Schlink, B. 1995. Der Vorleser. Zürich: Diogenes.

Schneider, J. and S. von der Emde. 2006. Dialogue, conflict, and intercultural learning in online collaborations between language learners and native speakers. In J. Belz and S. L. Thorne (eds). Computer-mediated intercultural foreign language learning. Boston, MA: Heinle \& Heinle. pp. 178-206.

Twigg, C. A. 2003. Improving learning and reducing costs: New modes for online learning. EDUCAUSE Review September/October: 28-38.

Von der Emde, S. and J. Schneider. 2003. Experiential learning and collaborative reading: Literacy in the space of virtual encounters. In P. Patrikis (ed.) Between the lines: perspectives on foreign language literacy. New Haven, CT: Yale University Press. pp 118-143.

Warschauer, M. and R. Kern. 2000. Network-based language teaching: Concepts and practice. Cambridge: Cambridge University Press. 


\section{Biographical note}

Stephan Mühr taught German to immigrants at the Hamburger Volkshochschule for eight years. His dissertation, published by Peter Lang in 2001, focuses on intercultural hermeneutics. He has also published on concepts of nature perception and post-colonial discourse. He joined the Department of Modern European Languages at the University of Pretoria, South Africa, as a senior lecturer in 2006, and has been the acting Head of Department since 2007. 